\title{
Finansowe wsparcie polskiego pszczelarstwa środkami Unii Europejskiej
}

\section{Wstęp}

Pszczelarstwo jest jednym z najstarszych zajęć człowieka. Przez wieki za korzyści wynikające $\mathrm{z}$ chowu pszczół uważano miód i inne produkty pszczele. Jednak najważniejszy efekt pracy pszczół wynika z zapylania roślin, co dotyczy głównie właścicieli zapylanych roślin uprawnych, a także, w przypadku roślin dziko rosnących, wszystkich ludzi. Ograniczona możliwość zastąpienia pszczół w zapylaniu roślin powoduje niemożność rezygnacji z chowu tych owadów bez negatywnego wpływu na uprawy roślin entomofilnych i środowisko przyrodnicze. Stanowi to podstawę do interwencji państwa i wsparcia pszczelarstwa. W krajach członkowski Unii Europejskiej działania te odbywają się w ramach wspólnej polityki rolnej.

Wspólna polityka rolna (WPR) Unii Europejskiej ma za zadanie prowadzenie działań poprawiających sytuację w rolnictwie krajów członkowskich. Jednym z takich działań jest mechanizm „Wsparcie rynku produktów pszczelich”, którego celem jest poprawa w sektorze pszczelarskim, zwłaszcza warunków pozyskiwania i wprowadzania na rynek miodu oraz innych produktów pszczelich [Bolisęga 2004].

\section{Cel i metody badań}

Celem pracy jest przedstawienie wielkości i struktury wsparcia pszczelarstwa w Polsce w ramach mechanizmu WPR ,Wsparcie rynku produktów pszczelich" oraz próba oceny wyników tego programu. 
Głównym materiałem źródłowym wykorzystanym w pracy były dane pochodzące z Agencji Rynku Rolnego (ARR), Oddziału Pszczelnictwa Instytutu Ogrodnictwa oraz z literatury przedmiotu. Dane z ARR dotyczyły wielkości wsparcia pszczelarstwa $\mathrm{w}$ ramach mechanizmu WPR „Wsparcie rynku produktów pszczelich”, a dane z Oddziału Pszczelnictwa dotyczyły znaczenia i charakterystyki pszczelarstwa w Polsce.

Do opracowania oraz oceny materiału badawczego wykorzystano następujące metody: opisową, porównawczą, tabelaryczną, graficzną oraz analizy przyczynowo-skutkowej.

\section{Wsparcie rynku produktów pszczelich w ramach WPR}

Jednym z elementów wspólnej polityki rolnej UE jest wsparcie działań, które mają na celu poprawę sytuacji w sektorze pszczelarskim. Działanie to dotyczy głównie warunków pozyskiwania i wprowadzania na rynek miodu i innych produktów pszczelich. Mechanizm ten działa w UE od 1997 roku. Państwa zainteresowane wsparciem pszczelarstwa w ramach tego mechanizmu składaja do akceptacji Komisji Europejskiej roczny, a od 2004 roku trzyletni, program wsparcia pszczelarstwa, w którym przedstawiają działania przewidywane do realizacji w danym kraju. Programy te powinny zawierać: opis sytuacji w sektorze pszczelarskim, określenie celu programu oraz opis planowanych działań, a także spis organizacji pszczelarskich współpracujących przy tworzeniu projektu i listę aktów prawnych regulujących sytuację w pszczelarstwie w danym kraju [Bolisęga 2004, Witkowska 2007].

Komisja Europejska określiła kierunki wsparcia pszczelarstwa w ramach tego mechanizmu. Należą do nich:

I. Pomoc techniczna dla pszczelarzy i organizacji.

II. Kontrola warrozy.

III. Racjonalne przemieszczanie rodzin pszczelich na pożytki.

IV. Działania wspierające laboratoria przeprowadzające analizy właściwości fizyko-chemicznych miodu.

V. Działania wspierające odbudowę pogłowia rodzin pszczelich.

VI. Współpraca z wyspecjalizowanymi jednostkami w ramach programów badawczych w sektorze pszczelarskim i produktów pszczelich.

Państwa UE mogą dowolnie wybierać kierunki wsparcia, w których chcą uczestniczyć, jak również określać szczegółowo działania planowane do realizacji. Polska bierze udział we wszystkich kierunkach działań.

Finansowanie działań w ramach omawianego mechanizmu odbywa się wspólnie przez państwa członkowskie i UE. Budżet Unii pokrywa do 50\% kosz- 
tów kwalifikowanych. Podział środków między kraje członkowskie odbywa się na podstawie liczby rodzin pszczelich. Pula środków przeznaczonych na wsparcie pszczelarstwa w UE jest rozdysponowana zgodnie z udziałem liczby pni pszczelich w danym państwie w ogólnej liczbie rodzin pszczelich na obszarze UE [Bolisęga 2004].

Polska uczestniczy w mechanizmie wsparcia pszczelarstwa od momentu wejścia w struktury UE. Mechanizm ten realizowany jest przez ARR i nosi nazwę „Wsparcie rynku produktów pszczelich”. Od czasu wejścia Polski do UE opracowano i zrealizowano trzy 3-letnie programy: „Krajowy program wsparcia pszczelarstwa w Polsce w latach 2004/2005, 2005/2006, 2006/2007”, „Krajowy program wsparcia pszczelarstwa w Polsce w latach 2007-2010” i „Krajowy program wsparcia pszczelarstwa w Polsce na latach 2010/2011, 2011/2012, 2012/2013". Kolejny 3-letni program (na lata 2014-2016) Komisja Europejska zatwierdziła 18 lipca 2013 roku. Wysokość wsparcia sektora pszczelarskiego $\mathrm{w}$ ramach tego mechanizmu pozostanie na zbliżonym poziomie do poprzedniego okresu.

\section{Pszczelarstwo w Polsce - potrzeba wsparcia}

Liczba rodzin pszczelich w Polsce od 2006 roku ma tendencję wzrostowa. Według danych gromadzonych przez powiatowych lekarzy weterynarii, na koniec 2006 roku liczba pni pszczelich wynosiła ponad 1090 tys., na koniec października 2009 roku ponad 1123 tys. [Semkiw i Ochal 2010], a na koniec października 2012 roku ponad 1280 tys. [Semkiw 2012]. Największe zagęszczenie rodzin pszczelich w 2012 roku występowało w Polsce południowej, zwłaszcza w województwach małopolskim, podkarpackim i lubelskim. Z kolei najniższe napszczelenie występowało $\mathrm{w}$ województwach podlaskim, pomorskim oraz $\mathrm{w}$ Polsce centralnej (tab. 1). Produkcja miodu w Polsce podlega znacznym wahaniom. W latach 2000-2012 wahała się od ok. 9 tys. ton w 2004 roku do 23 tys. ton w 2011 roku. Przeciętnie w okresie tym produkowano ok. 15-17 tys. ton miodu rocznie [Majewski 2008, Pszczelarstwo... 2012, Semkiw 2012].

Liczba pszczelarzy w Polsce w 2012 roku przekraczała 50 tys. osób. Najwięcej z nich zamieszkiwało tereny południowej Polski. Pszczelarze z województw małopolskiego, lubelskiego i podkarpackiego stanowili ponad 30\% ogółu. Najmniej pszczelarzy było natomiast na Podlasiu (tab. 1).

Pszczelarstwo pełni w życiu człowieka podwójną rolę, dostarczając produkty pszczele oraz zapylając rośliny entomofilne. Wartość produktów uzyskanych dzięki zapylaniu przez pszczoły jest wielokrotnie większa od wartości produktów pszczelich. Szacowana wartość zapyleń roślin uprawnych w USA w 2000 roku 
Tabela 1

Zróżnicowanie pszczelarstwa w Polsce według województw w 2012 roku

\begin{tabular}{|l|c|c|c|c|}
\hline Województwo & $\begin{array}{c}\text { Liczba } \\
\text { pszczelarzy }\end{array}$ & $\begin{array}{c}\text { Liczba rodzin } \\
\text { pszczelich [tys.] }\end{array}$ & $\begin{array}{c}\text { Średnia } \\
\text { wielkość } \\
\text { pasieki }\end{array}$ & $\begin{array}{c}\text { Liczba rodzin } \\
\text { pszczelich na km }{ }^{2} \\
\text { powierzchni }\end{array}$ \\
\hline Dolnośląskie & 3505 & 96,9 & 27,7 & 4,9 \\
\hline Kujawsko-pomorskie & 2430 & 63,3 & 26,1 & 3,5 \\
\hline Lubelskie & 5538 & 163,6 & 29,5 & 6,5 \\
\hline Lubuskie & 1721 & 46,3 & 26,9 & 3,3 \\
\hline Łódzkie & 2578 & 49,5 & 19,2 & 2,7 \\
\hline Małopolskie & 5860 & 113,6 & 19,4 & 7,5 \\
\hline Mazowieckie & 4285 & 94,5 & 22,0 & 2,7 \\
\hline Opolskie & 1648 & 33,1 & 20,1 & 3,5 \\
\hline Podkarpackie & 4972 & 122,7 & 24,7 & 6,9 \\
\hline Podlaskie & 1302 & 32,6 & 25,1 & 1,6 \\
\hline Pomorskie & 1746 & 50,5 & 28,9 & 2,8 \\
\hline Śląskie & 4897 & 64,2 & 13,1 & 5,2 \\
\hline Świętokrzyskie & 2037 & 55,6 & 27,3 & 4,7 \\
\hline Warmińsko-mazurskie & 2802 & 123,8 & 44,2 & 5,1 \\
\hline Wielkopolskie & 4213 & 102,0 & 24,2 & 3,4 \\
\hline Zachodniopomorskie & 2244 & 68,5 & 30,5 & 3,0 \\
\hline Ogółem & 51778 & 1280,7 & 24,7 & 4,1 \\
\hline
\end{tabular}

Źródło: Semkiw 2012 i obliczenia własne.

wynosiła 14,6 mld USD [Morse i Calderone 2000], a na świecie wartość tę w 2005 roku oszacowano na 153 mld euro [Gallai i in. 2009]. Z kolei w Polsce wartość zapylania głównych roślin uprawnych (rzepak, rośliny sadownicze oraz krzewy owocowe i plantacje trwałe) wyniosła od 0,6 do 1,2 mld PLN [Majewski 2011]. Liczby te wskazują na znaczenie pszczół dla rolnictwa, tym bardziej że efekty zapylania są konsumowane głównie przez właściciela roślin zapylanych przez te owady. Dodatkowo pszczoły, ze względu na zapylanie roślin dziko żyjących, mają korzystny wpływ na środowisko naturalne, stanowiąc ważny czynnik zachowania bioróżnorodności.

Znaczenie pszczół dla człowieka i środowiska oraz brak możliwości ich zastąpienia stanowią argument za wsparciem tej działalności. Czynnikiem wskazującym na potrzebę wsparcia pszczelarstwa są także warunki klimatyczne, które ograniczają możliwości konkurowania polskim pszczelarzom na światowym rynku produktów pszczelich. Wynika to m.in. z krótszego, w porównaniu z inny- 
mi regionami świata, okresu kwitnienia pożytków pszczelich, a co za tym idzie - niższej wydajności.

\section{Wartość wsparcia pszczelarstwa w Polsce}

Wartość wsparcia dla pszczelarstwa w Polsce w ramach mechanizmu „Wsparcie rynku produktów pszczelich" w dwóch pierwszych 3-letnich okresach wynosiło po ok. 13,3 mln euro, zaś w kolejnym okresie wzrosła do 15,09 mln euro (po $5,03 \mathrm{mln}$ euro rocznie).

Liczba projektów składanych do realizacji oraz zrealizowanych i rozliczonych w latach 2005-2012 zwiększyła się, a zmniejszył się odsetek projektów złożonych, które nie zostały rozliczone. W 2005 roku odrzucono około $40 \%$ złożonych projektów. W kolejnych dwóch latach udział projektów nierozliczonych wyniósł poniżej $20 \%$, a w ostatnich trzech badanych latach wahał się w przedziale $3-7 \%$ (rys. 1). Wskazuje to na coraz lepsze zrozumienie przez pszczelarzy $\mathrm{i}$ ich stowarzyszenia warunków uczestnictwa w mechanizmie.

Czynnikiem uniemożliwiającym pełne wykorzystanie środków z badanego mechanizmu jest nierozliczenie projektów przyjętych do realizacji. Liczba takich projektów wahała się od $4 \mathrm{w}$ latach 2010-2011 do 24 w 2005 roku i stanowiła odpowiednio od ok. 2 do niemal 10\% projektów przyjętych do realizacji (rys. 1).

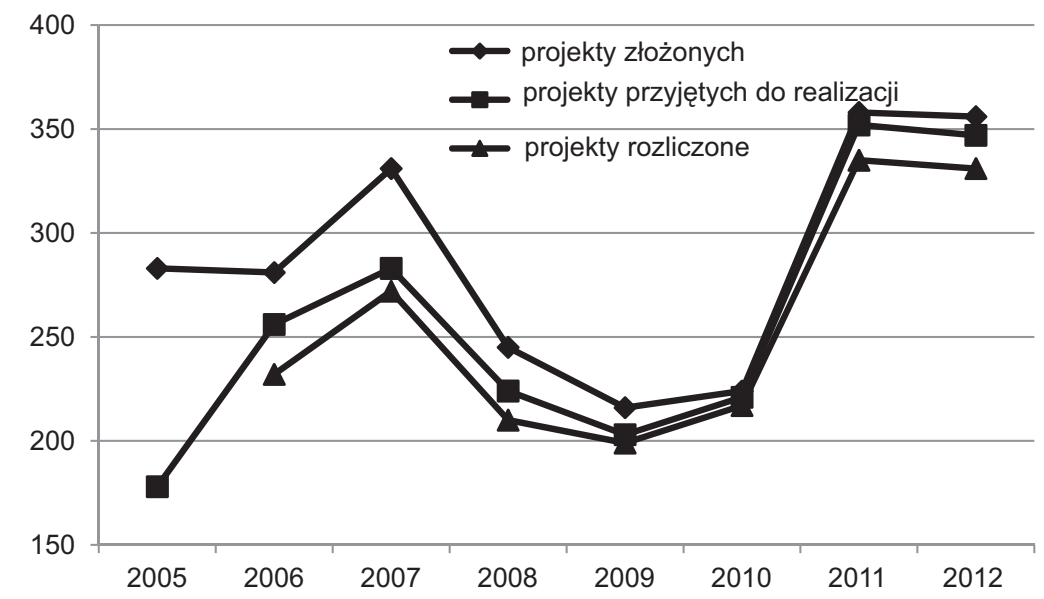

\section{Rysunek 1}

Liczba projektów złożonych, przyjętych do realizacji i rozliczonych w ramach programu wsparcia pszczelarstwa w Polsce w latach 2005-2012

Źródło: Sprawozdania ARR za lata 2006-2012, dane ARR. 
Spowodowało to niemożność wypłacenia pszczelarzom wsparcia w kwocie od ponad 5,1 mln zł w 2005 roku do 1,7-1,9 mln zł w latach 2009-2012 (rys. 2).

Polska uczestniczy we wszystkich działaniach wsparcia wskazanych w mechanizmie wsparcia pszczelarstwa, jednak przez lata największym zainteresowaniem pszczelarzy cieszyły się działanie II (zwalczanie warrozy) oraz V (odbudowa pogłowia rodzin pszczelich). W latach 2006-2010 wartość projektów przyjętych do realizacji na te zadania stanowiła od 70 do ponad $90 \%$ środków na wszystkie działania. W dwóch ostatnich badanych latach wzrosło znaczenie

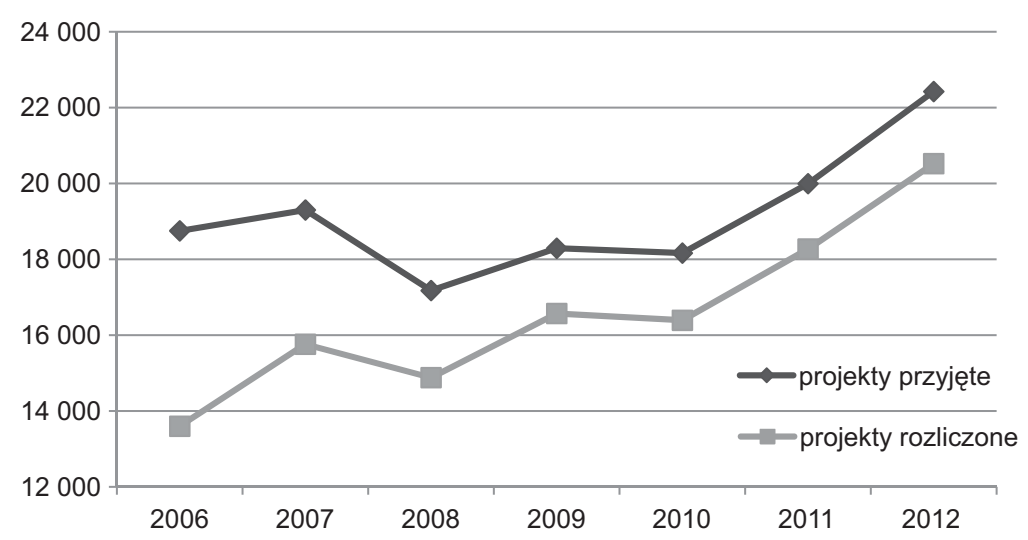

\section{Rysunek 2}

Wartość projektów przyjętych do realizacji i rozliczonych w latach 2006-2012 [tys. zł] Źródło: Jak pod rysunkiem 1.

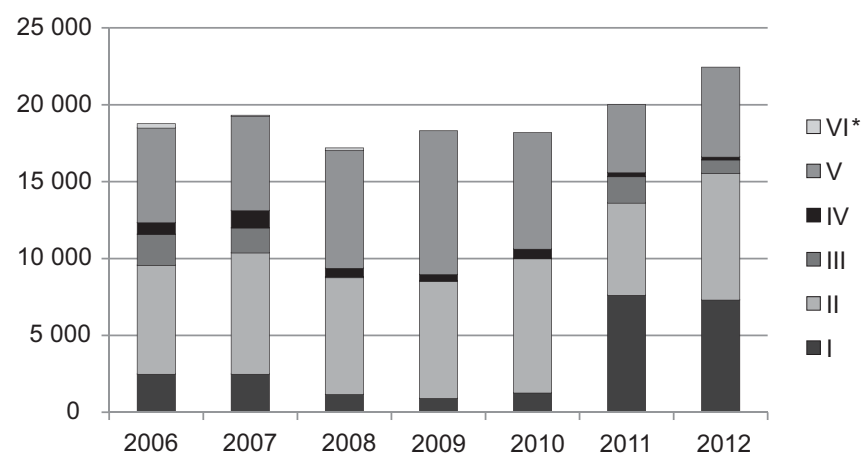

* Oznaczenia kierunków wsparcia zgodne z oznaczeniem użytym w tekście artykułu.

\section{Rysunek 3}

Wartość projektów przyjętych do realizacji w zależności od kierunku działań w latach 2005-2012 [tys. zł]

Źródło: Jak pod rysunkiem 1. 
Tabela 2

Przeciętna wartość projektu rozliczonego w zależności od kierunku wsparcia w latach 2006-2012 [tys. zł]

\begin{tabular}{|c|c|c|c|c|c|c|c|}
\hline $\begin{array}{c}\text { Rodzaj } \\
\text { wsparcia }\end{array}$ & 2006 & 2007 & 2008 & 2009 & 2010 & 2011 & 2012 \\
\hline I & 39,1 & 30,4 & 21,7 & 20,2 & 22,4 & 52,3 & 55,1 \\
\hline II & 69,6 & 88,7 & 87,6 & 94,6 & 99,7 & 91,2 & 110,4 \\
\hline III & 59,2 & 30,3 & 4,5 & 6,0 & 5,5 & 14,1 & 12,1 \\
\hline IV & 30,5 & 28,4 & 15,6 & 12,6 & 20,3 & 6,7 & 6,3 \\
\hline $\mathrm{V}$ & 68,4 & 75,4 & 98,3 & 124,5 & 105,3 & 60,6 & 72,5 \\
\hline $\mathrm{VI}$ & 50,0 & 6,5 & 23,5 & - & - & - & - \\
\hline Ogółem & 58,6 & 57,9 & 70,9 & 83,3 & 75,5 & 54,5 & 62,0 \\
\hline
\end{tabular}

Źródło: Obliczenia własne na podstawie danych ARR.

projektów przyjętych do realizacji na działanie I (pomoc techniczna dla pszczelarzy). Ich udział w tych latach wynosił ponad $30 \%$. Z kolei działania VI i IV w niewielkim stopniu interesowały pszczelarzy. Od 2009 roku na działanie VI nie przyjęto do realizacji żadnego projektu, a środki przeznaczone na zadanie IV stanowiły w badanym okresie przeciętnie ok. 3\% wszystkich środków (rys. 3).

Przeciętna wartość rozliczonych projektów wahała się od niespełna 60 tys. zł w latach 2006-2007 do ponad 80 tys. zł w 2009 roku. Brak wzrostu wartości projektów w czasie wskazuje na coraz mniejszą realną wartość wsparcia dla uczestniczących w nim pszczelarzy. Najwyższe przeciętne wartości uzyskano w przypadku działań II i V (tab. 2). Może to wynikać z popularności tych dwóch działań i udziału w nich większej liczby pszczelarzy niż w przypadku innych kierunków działań.

\section{Regionalne zróżnicowanie wielkości wsparcia dla pszczelarstwa w Polsce}

Wsparcie dla pszczelarstwa, podobnie jak samo pszczelarstwo, jest zróżnicowane regionalnie. Największy udział w pozyskanych środkach w 2012 roku miało województwo lubelskie (16\%), w którym użytkuje się najwięcej pni pszczelich w Polsce. Relatywnie dużo środków pozyskano także w województwach wielkopolskim, małopolskim, mazowieckim i dolnośląskim. Ich udział w środkach na wsparcie pszczelarstwa wynosił od 8 do $11 \%$ i wynikał ze znacznej liczby pszczelarzy i rodzin pszczelich w tych województwach. Najmniejszy udział w pozyskiwaniu środków na wsparcie pszczelarstwa w 2012 roku posia- 
dały natomiast województwa podlaskie $(1 \%)$ i opolskie $(2 \%)$, które charakteryzują się także najniższą liczbą pszczelarzy i rodzin pszczelich w Polsce.

Struktura wykorzystania uzyskanych na wsparcie pszczelarstwa środków w poszczególnych województwach w 2012 roku była podobna (tab. 3). We wszystkich województwach najwięcej środków przeznaczono na zakup leków. Przeciętnie na ten cel wydawano niemal 39\% środków, przy wahaniach od 34 do $44 \%$. Po około $1 / 4$ kwoty wsparcia przeznaczono na zakup sprzętu pszczelarskiego i zakup pszczół, a na pozostałe działania niespełna 10\% środków.

Przeciętna kwota wsparcia przypadająca na jeden zrealizowany wniosek w latach 2011-2012 wyniosła około 60 tys. zł (rys. 4). Przy czym wystapiło znaczne zróżnicowanie regionalne w wypłacanych kwotach. Najniższa wartość

Tabela 3

Wartość i struktura wsparcia w ramach mechanizmu wsparcie produkcji i zbytu miodu w zależności od kierunków wsparcia i województw w 2012 roku

\begin{tabular}{|c|c|c|c|c|c|c|c|}
\hline \multirow[b]{2}{*}{ Województwo } & \multirow[b]{2}{*}{$\begin{array}{c}\text { Wartość } \\
\text { wsparcia } \\
\text { [tys. zł] }\end{array}$} & \multicolumn{6}{|c|}{ Udział wsparcia na [\%] } \\
\hline & & $\begin{array}{l}\text { zakup } \\
\text { leków }\end{array}$ & $\begin{array}{c}\text { zakup sprzętu } \\
\text { pszczelarskiego }\end{array}$ & $\begin{array}{c}\text { zakup } \\
\text { pszczół }\end{array}$ & szkolenia & $\begin{array}{l}\text { zakup } \\
\text { lawet }\end{array}$ & $\begin{array}{c}\text { analizy } \\
\text { jakości } \\
\text { miodu }\end{array}$ \\
\hline Dolnośląskie & 1553 & 40,8 & 28,3 & 21,3 & 6,6 & 2,9 & 0,1 \\
\hline $\begin{array}{l}\text { Kujawsko- } \\
\text {-pomorskie }\end{array}$ & 959 & 42,5 & 30,7 & 18,7 & 7,2 & 0,9 & 0,0 \\
\hline Lubelskie & 3205 & 34,3 & 25,1 & 33,7 & 2,8 & 3,7 & 0,4 \\
\hline Lubuskie & 732 & 43,3 & 27,6 & 15,0 & 10,7 & 2,0 & 1,4 \\
\hline Łódzkie & 859 & 43,7 & 29,3 & 21,8 & 3,1 & 2,1 & 0,0 \\
\hline Małopolskie & 1725 & 38,6 & 20,9 & 25,5 & 11,4 & 2,3 & 1,3 \\
\hline Mazowieckie & 1581 & 38,8 & 23,5 & 26,4 & 6,6 & 2,9 & 1,7 \\
\hline Opolskie & 506 & 38,1 & 25,1 & 25,1 & 6,3 & 3,2 & 2,2 \\
\hline Podkarpackie & 1267 & 41,6 & 26,8 & 24,4 & 4,8 & 1,4 & 1,0 \\
\hline Podlaskie & 221 & 35,7 & 20,8 & 26,7 & 14,0 & 2,7 & 0,0 \\
\hline Pomorskie & 1038 & 39,0 & 24,6 & 27,4 & 4,0 & 5,0 & 0,0 \\
\hline Śląskie & 1470 & 39,7 & 28,7 & 24,4 & 5,3 & 1,4 & 0,5 \\
\hline Świętokrzyskie & 774 & 40,7 & 30,4 & 22,1 & 3,0 & 3,5 & 0,4 \\
\hline $\begin{array}{l}\text { Warmińsko- } \\
\text {-mazurskie }\end{array}$ & 1393 & 39,1 & 26,0 & 30,2 & 2,3 & 2,3 & 0,2 \\
\hline Wielkopolskie & 2330 & 36,1 & 30,3 & 24,7 & 5,2 & 3,5 & 0,3 \\
\hline $\begin{array}{l}\text { Zachodnio-po- } \\
\text { morskie }\end{array}$ & 909 & 38,7 & 31,2 & 18,8 & 8,5 & 2,8 & 0,0 \\
\hline Ogółem & 20522 & 38,7 & 26,8 & 25,4 & 5,7 & 2,8 & 0,6 \\
\hline
\end{tabular}

Źródło: Jak w tabeli 2. 
wystapiła w województwie podlaskim, gdzie wielkość kwoty wypłaconej na jeden zrealizowany projekt wyniosła $12-13$ tys. zł. Najwyższą przeciętną kwotę wsparcia na projekt wypłacano natomiast na Lubelszczyźnie. Zróżnicowanie to może wynikać z przeciętnej liczby pszczelarzy uczestniczących $\mathrm{w}$ jednym projekcie. Kwota wsparcia pszczelarza jest ograniczona i uzależniona od liczby posiadanych rodzin pszczelich. Zatem duża liczba uczestników w projekcie wpływa na wzrost kwoty wsparcia w przeliczeniu na projekt. Nie uzyskano jednak istotnej zależności między przeciętną wartością projektu w województwie a liczbą rodzin pszczelich lub liczbą pszczelarzy na tym obszarze.

Miernikiem, który może wskazać aktywność pszczelarzy w zdobywaniu środków wsparcia na ich działalność, może być uzyskana kwota wsparcia przypadająca na pszczelarza lub rodzinę pszczelą. Przeciętnie w 2012 roku pszcze-

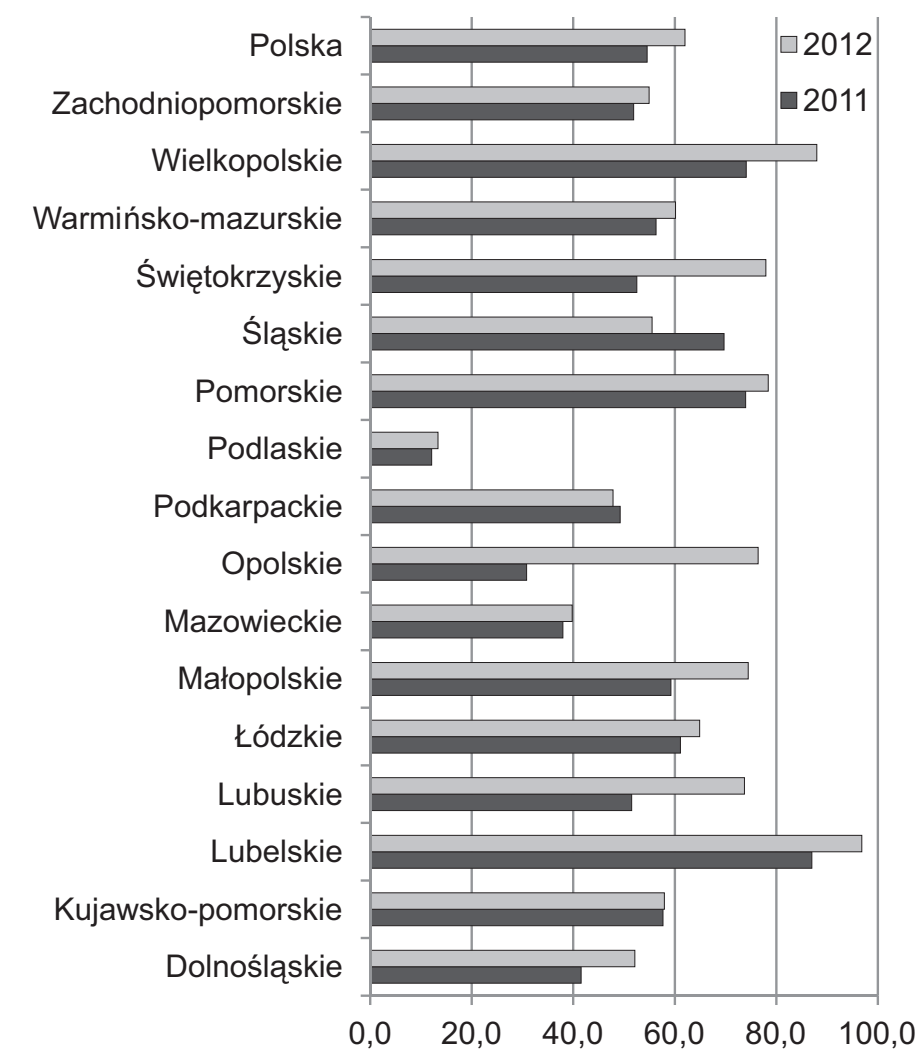

\section{Rysunek 4}

Zróżnicowanie regionalne kwoty wypłaconej na jeden zrealizowany wniosek w latach 2011-2012 [tys. zł]

Źródło: Obliczenia własne na podstawie Semkiw 2012 i danych ARR. 
larz otrzymał wsparcie z badanego programu w kwocie niemal 400 zł, a na jedną rodzinę pszczelą przypadało przeciętnie $16 \mathrm{zł}$ (tab. 4).

Najwyższe wsparcie w przeliczeniu na pszczelarza uzyskano w województwach pomorskim (595 zł), lubelskim (579 zł) i wielkopolskim (553 zł), najniższą wartość uzyskano natomiast na Podlasiu (170 zł). Pszczelarze w województwie podlaskim uzyskali także najniższą przeciętną wartość wsparcia w przeliczeniu na rodzinę pszczelą (niespełna 7 zł). Z kolei najwyższe wartości wsparcia na pień pszczeli uzyskano w województwach śląskim, wielkopolskim i pomorskim (tab. 4).

Różnice $\mathrm{w}$ wartościach wsparcia $\mathrm{w}$ przeliczeniu na pszczelarza i rodzinę pszczelą mogą wynikać z jednej strony z aktywności pszczelarzy. Podmiotami uprawnionymi do ubiegania się o wsparcie są głównie związki i stowarzyszenia pszczelarskie oraz spółdzielnie i grupy producenckie pszczelarzy, zatem pszczelarze niezrzeszeni mogą mieć trudności związane z możliwością skorzystania

\section{Tabela 4}

Przeciętna wartość wsparcia przypadająca na pszczelarza i rodzinę pszczelą w województwach w 2012 roku [zł]

\begin{tabular}{|l|c|c|}
\hline \multirow{2}{*}{ Województwo } & \multicolumn{2}{|c|}{ Przeciętna wartość wsparcia przypadająca na: } \\
\cline { 2 - 3 } & pszczelarza & rodzinę pszczelą \\
\hline Dolnoślaskie & 443,1 & 16,0 \\
\hline Kujawsko-pomorskie & 394,7 & 15,1 \\
\hline Lubelskie & 578,7 & 19,6 \\
\hline Lubuskie & 425,3 & 15,8 \\
\hline Łódzkie & 333,2 & 17,3 \\
\hline Małopolskie & 294,4 & 15,2 \\
\hline Mazowieckie & 369,0 & 16,7 \\
\hline Opolskie & 307,0 & 15,3 \\
\hline Podkarpackie & 254,8 & 10,3 \\
\hline Podlaskie & 169,7 & 6,8 \\
\hline Pomorskie & 594,5 & 20,6 \\
\hline Śląskie & 300,2 & 22,9 \\
\hline Świętokrzyskie & 380,0 & 13,9 \\
\hline Warmińsko-mazurskie & 497,1 & 11,3 \\
\hline Wielkoolskie & 553,1 & 22,8 \\
\hline Zachodniopomorskie & 405,1 & 13,3 \\
\hline Ogółem & 396,3 & 16,0 \\
\hline
\end{tabular}

Źródło: Jak pod rysunkiem 4. 
z pomocy. Z kolei pszczelarze, którzy są właścicielami gospodarstwa o wielkości ekonomicznej 4 ESU bądź większego nie mogą korzystać z opisanego mechanizmu wsparcia, co powoduje zmniejszenie obliczonej w tabeli 4 przeciętnej wartości pomocy, zwłaszcza w przeliczeniu na rodzinę pszczela.

\section{Podsumowanie i wnioski}

Pszczelarstwo, przede wszystkim ze względu na znaczenie pszczół w zapylaniu roślin, odgrywa duże znaczenia dla rolnictwa i środowiska naturalnego. Pozytywną tendencją jest wzrost liczby rodzin pszczelich w Polsce. Efekty zapylania dokonywanego przez pszczoły w niewielkim stopniu wracają do pszczelarzy, a głównie konsumowane są przez osoby trzecie. Może to stanowić podstawę do ochrony i wsparcia rynku pszczelarskiego w UE. W ramach WPR od 1997 roku działa mechanizm wsparcia pszczelarstwa, którego celem jest poprawa sytuacji na tym rynku.

W Polsce mechanizm wsparcia pszczelarstwa w ramach WPR działa od momentu akcesji do UE. Liczba złożonych przez uprawnione instytucje wniosków w badanym okresie wzrosła. Także wykorzystanie środków w ostatnich badanych latach było wyższe niż w okresie początkowym. Świadczy to o dostosowaniu się wnioskodawców do reguł wsparcia. Korzystną sytuacją był wzrost wartości rozliczonych wniosków z niespełna $14 \mathrm{mln}$ zł w 2006 roku do ponad $20 \mathrm{mln}$ zł w $2012 \mathrm{r}$.

Wsparcie pszczelarstwa w Polsce w 2012 roku było zróżnicowane regionalnie. Najwyższe przeciętne kwoty wsparcia w przeliczeniu na pszczelarza otrzymywano w województwach pomorskim, lubelskim i wielkopolskim (po ok. 550$-595 \mathrm{zf})$, najniższe zaś w podlaskim (170 zł). Z kolei w przeliczeniu na pień pszczeli największe wsparcie przypadało w województwach pomorskim, śląskim i wielkopolskim (po ok. 21-23 zł), a najmniej również w podlaskim (7zł).

Przeprowadzone badania pozwalają na sformułowanie wniosków dotyczących pszczelarstwa i jego wsparcia w Polsce:

1. Wsparcie pszczelarstwa po akcesji Polski do Unii Europejskiej może być jednym z powodów wzrostu liczby rodzin pszczelich.

2. Nierozliczenie wszystkich przyjętych do realizacji projektów spowodował, że w latach 2008-2012 niewykorzystanych zostało ok. 10\% dostępnych środków. Dobrze byłoby wprowadzić rozwiązanie, które pozwoli na wykorzystanie wszystkich dostępnych środków.

3. Głównymi kierunkami wsparcia, na które składano projekty, były działania II i V oraz w latach 2011-2012 działanie I. Natomiast na działanie VI w latach 2009-2012 nie złożono żadnego projektu. Wskazuje to na potrzebę zre- 
widowania kierunków działań, a także wprowadzenie nowych, np. działania ułatwiające chów pszczół młodym pszczelarzom.

4. Ograniczenie wsparcia pszczelarstwa do gospodarstw o wielkości ekonomicznej poniżej 4 ESU może ograniczać liczbę pasiek zawodowych. By zwiększyć produkcję miodu w Polsce, należy wspierać pasieki towarowe, np. w ramach innych mechanizmów wsparcia.

5. Wysokość wsparcia pszczelarstwa w Polsce była w 2012 roku zróżnicowana regionalnie, co wynika z zainteresowania pszczelarzy tą formą pomocy. Wydaje się potrzebne wprowadzenie zachęt do chowu pszczół, zwłaszcza w regionach Polski o najniższym napszczeleniu. Pozwoli to ograniczyć straty wynikające z braku owadów zapylających.

\section{Literatura}

BOLISĘGA E., 2004: Wsparcie produkcji i zbytu miodu, Biuletyn informacyjny ARR, 12(162), s. 32-36.

BOLISĘGA E., 2009: Wsparcie rynku produktów pszczelich - podsumowanie sezonu 2008/2009, Biuletyn informacyjny ARR 12(222), s. 26-33.

GALLAI M., SALLES J.M., SETTELE J., VAISSIČRE B.E., 2009: Economic valuation of the vulnerability of world agriculture confronted with pollinator decline, Ecological Eonomics 68.

MAJEWSKI J., 2010: Straty wynikajace z niewystarczajace liczby zapylaczy - próba szacun$k u$, Roczniki Naukowe SERiA t. XII, z. 1, s. 122-127.

MAJEWSKI J., 2011: Wartość zapyleń roślin uprawnych $w$ Polsce, Prace Naukowe Uniwersytetu Ekonomicznego we Wrocławiu, 166, s. 112-120.

MORSE R.A., CALDERONE N.W., 2000: The value of honey bees as pollinators of U.S. crops in 2000, Bee Culture 128.

Pszczelarstwo i rynek miodu w Polsce, 2012: Materiały Ministerstwa Rolnictwa i Rozwoju Wsi, http://www.minrol.gov.pl/pol/Ministerstwo/Biuro-Prasowe/Informacje-Prasowe/ Pszczelarstwo-i-rynek-miodu (data dostępu: maj 2012).

SEMKIW P., OCHAL J., 2010: Sektor pszczelarski w Polsce - dane aktualne (część I), Pszczelarstwo 5.

SEMKIW P., 2012: Sektor pszczelarski w Polsce w 2012 roku, http://www.opisik.pulawy. $\mathrm{pl} /$ ?q= node/110, (data dostępu: grudzień 2013).

Sprawozdanie Agencji Rynku Rolnego (2005-2012 passim), http://bip.arr.gov.pl/index. php?id Dzialu=00167 (data dostępu: luty 2014).

Witkowska A., 2007: Wsparcie rynku produktów pszczelich - sezon 2005/2006, Biuletyn informacyjny ARR nr 2(188), s. 10-16. 


\section{Abstrakt}

Pszczelarstwo stanowi ważny element rolnictwa. Celem pracy było określenie wielkości i struktury wsparcia pszczelarstwa po akcesji Polski do UE. Zaprezentowano wielkość i warunki wsparcia pszczelarstwa w ramach mechanizmu WPR Wsparcie rynku produktów pszczelich. Liczba wniosków o pomoc oraz wartość pomocy w ramach tego mechanizmu w latach 2005-2012 wzrosła.

Wielkość wsparcia pszczelarstwa była zróżnicowana regionalnie. Najwyższe wsparcie występowało w województwach lubelskim, wielkopolskimi pomorskim, najniższe zaś w podlaskim. Zasadne jest kontynuowanie działań wspierających ten sektor rolnictwa ze względu na jego wagę dla produkcji roślinnej i środowiska naturalnego.

Słowa kluczowe: Polska, pszczelarstwo, wsparcie, zróżnicowanie regionalne

\section{The financial support of Polish beekeeping by European Union's funds}

\section{Abstract}

Beekeeping is an important part of agriculture. The aim of the study was to determine the volume and structure of support for beekeeping after Polish accession to the EU. The volume and conditions of apiculture support under the mechanism of the CAP Support bee products market were presented. The number of applications for assistance and the amount of aid under this mechanism increased in 2005-2012.

The amount of support for beekeeping differed by regions. The highest support was observed in the regions of Lublin, Wielkopolska and Pomerania and the lowest was in Podlasie. It is reasonable to continue actions in support of the agricultural sector, due to its importance for plant production and the environment.

Key words: Poland, beekeeping, support, regional differentiation 
